Hasan Tutar,

Dr.Sc., Professor, Anadolu University, Turkey

Omer Karademir,

Sakarya University, Turkey

Sevilay Guler,

Sakarya University, Turkey

Salih Tutar,

Sakarya Applied Science University, Turkey

\title{
MANAGEMENT OF INNOVATIONS IN EDUCATION: STUDENTS SATISFACTION AND CAREER ADOPTABILITY
}

\begin{abstract}
Open and distance education, unlike the traditional style of education, does not have to come to the campus, courses are processed in a completely virtual environment through the computer, live and interactive is the name of the training that the participant can watch them again and again at any time. Open and distance education in this aspect; Student Centre is an ideal educational model for people who cannot benefit from traditional education, providing equal opportunities, providing education opportunities for physically disabled students, eliminating geographical and regional barriers. Besides, it is a modern and innovative education model that ensures the continuation of the education of the people working in their businesses. Career compliance is a process that starts from preparation for the profession and starts from employment, progress in career and ending a career. Career compliance reflects an individual's capacity to cope with potential changes that may arise in the present and future business life. Besides, employees' level of coping with new job responsibilities, unexpected career changes and the ability to overcome obstacles that may arise. The main purpose of this study is to examine the relationship between education satisfaction levels and career adaptability perceptions of participants taking education within open or distance education model. The study is important in terms of developing and improving the open or distance education model when considering that the number of people taking education within the open or distance education model in our country is more than three and a half million today. Besides, one of the important issues in working life in contemporary societies is the career issue and it is thought that the adaptability of employees with their occupations has an important role in their productivity. Therefore, determining the level of educational satisfaction and career adaptability is thought to be important. In the study, which is based on «lifelong learning theory", the quantitative research method was preferred. To collect data, the "Distance Education Satisfaction Scale» and the "Career-related Adoptability» scales were employed. Data collected from a sample of 527 individuals were analysed by difference, relationship and impact tests and it was found that distance education satisfaction had a positive effect on career adaptability.
\end{abstract}

Keywords: education satisfaction, career adaptability, distance education, open education, e-learning.

Introduction. Recent developments in information and communication technologies have led to significant changes in educational models, and the need for people to adapt to changing and developing conditions has led to the emergence of new educational techniques and methods. As Moore and Kearsley (2011) pointed out, today's business and private life are intertwined, temporal and spatial boundaries have begun to disappear, and relatively flexible educational models have been developed with the ability to meet the needs of this new situation. A distance learning method that offers the flexibility and freedom opportunity for individuals has recently attracted attention as a highly preferred model. Open or distance education is a process in which learners and teachers can come together without space and time limitation, the interaction between the learner and the teacher is provided by various communication technologies, which can be realized in different ways according to different education levels and course contents and therefore requires a unique course design and arrangements. This process also provides

Cite as: Tutar, H., Karademir, O., Guler, S. \& Tutar, S. (2019). Management of Innovations in Education: Students Satisfaction and Career Adoptability. Marketing and Management of Innovations, 4, 321-335. http://doi.org/10.21272/mmi.2019.4-25 

Adoptability

important opportunities for lifelong learning, which is one of the learning models and has recently formed the theoretical basis of this research.

Knapper and Cropley (1991) stated that lifelong learning term is perceived in different ways, and it is developed as an alternative model in addition to traditional formal education. Unlike lifelong learning, lifelong learning theory is an interactive educational model that is conducted in a new, flexible and virtual environment that requires participation not only by certain professionals but also within a broader framework. Longworth and Davies (1996) describe «lifelong learning as a process motivating people in their production process and intellectual satisfaction, encouraging and supporting them to gain new experiences throughout life by revealing their potential». Moxley and Wilson (1998) suggested that lifelong learning will increase the level of awareness related to self and the environment. Distance education facilitates lifelong learning by offering alternative learning opportunities, eliminating the temporal and spatial barriers of learning, and increasing access to education. The opportunities offered by distance education model make it easier for people to gain different experiences and to manage changes. As Michael and Jones (2012) noted, although lifelong learning encompasses formal and distance learning, the focus is on lifelong learning enhancing «uninterrupted education».

Literature Review. In Turkey «open education» concept is generally used for applications which provide internet-based, relatively low cost non-formal education opportunities for broad masses. In Turkey, this education opportunity is offered by the Open Education Faculty, Faculty of Economics and Business Administration within Anadolu University. Open Education Faculties of Istanbul University and Ataturk University are other universities that offer this opportunity. Another application like the Open Education system in distance education. This model expresses the applications that necessitate students to come to campuses due to various reasons such as exam or practice courses and presenting the classes informal education programs via internet-based distance education (Aydin 2011). There are many universities in Turkey that provide distance education opportunities. The number of «open education» students studying at associate and undergraduate level is 3,586,216 while the number of «distance education» students in associate degree, bachelor's and master's degrees is 86,473 . In this research, the main emphasis is on determining career adaptability levels of students studying at open and distance education systems which are assumed to be one of the criteria of qualified education.

$\mathrm{H} 1$. The individual characteristics and educational satisfaction and career adaptability perception levels of open and distance students differ significantly.

Although there are many traditional (formal) universities in Turkey, there are some problems such as lack of enough capacity, distance and sometimes lack of adequate and qualified instructors. Besides, some people are deprived of education due to responsibilities such as work and family, although they want to receive an education. Open or distance education offers alternative opportunities in education to groups with similar disadvantages. Interaction between open and distance learners and teachers is provided through interactive communication systems and is carried out under an institutional structure (Schlosser \& Simonson, 2009). The features of distance education model, in general, can be listed as follows (Ozer 1990):

- learners and teachers are physically present in different environments;

- it is applied within an institutional structure;

- in distance education, the learners are mostly composed of the masses who are between 18-40 years old and who continue their working life and education at the same time;

- various teaching environments such as printed materials, radio, television and computerized internet technologies are employed and are often used to complement each other;

- in the distance education model, student support services are provided to provide the students with the information they need concerning teaching and non-teaching subjects to establish relations with the distance education institution. 

Adoptability

Open and distance education, which provides education with techniques and methods with a different understanding from the traditional education method differs from the traditional (formal) education model in many ways. These differences can be identified as follows (Verduin and Clark, 1994; Kosar et al. 2003; Eygu \& Kahraman 2013):

- the presence of teachers and students in geographically separate places;

- the use of educational media that combines the instructor and the learner with interactive processes and conveys the course content through a virtual environment;

- possibility of bringing teacher, student and course contents together;

- ensuring full independence from space or time;

- the learner learns by his own will without being under the influence of the teacher;

- changing course periods according to the person;

- allowing individuals to receive this training in synchronous and asynchronous ways;

- being an effective tool in providing lifelong learning.

According to Savickas (2011), who conducted important researches on career adaptability in literature, meta-competencies such as identity and adaptability, are the levels of providing individuals with the capacity to change whenever he/she needs to change. In today's world where change is taking place very quickly, a good career in working life necessitates lifelong learning and being highly qualified in horizontal and crossways, not vertically progressing in a single field of expertise. This method, which is called a multicareer system, also contributes to individuals' higher job satisfaction without the feeling of monotony. The occupational decision of an individual in young adulthood or a job that looks attractive at that time may lose its validity in the future (Savickas 1997). The ability to cope with this problem that individuals face in business life is expressed as career adaptability. According to Super and Knasel (1981), career adoptability is the ability of a professional to cope with changing professions and working conditions. On the other hand, Savickas (1997) stated that career adoptability means that an individual is ready to overcome the tasks that are likely to be encountered in the process of preparing or taking part in a professional role.

Career adoptability which ensures readiness for current and future changes in the business itself or working conditions consists of four dimensions namely interest, curiosity, control and trust (Savickas \& Porfeli, 2012). The interest expresses the preparation of the person for career future, future life and career planning. Curiosity explains the ability to explore the harmony between one's self and professions and discover opportunities that are appropriate for him/ her. Control is related to the sense of responsibility of the individual to build his/her career and to believe that he/she is competent. Trust expresses his belief that he/she will get positive results in career choice and feels that he/she can overcome the obstacles he/she may face during his/her career.

$\mathrm{H}$ 2. There is a significant relationship between the participants' perceptions of distance education satisfaction and their career adoptability.

It is thought that there may be a relationship between the level of career adaptability, which is defined as the ability to cope with the obstacles that an individual may face in his/her career journey and the level of education satisfaction of the individual. Higher education institutions have a significant share in the education sector and, like any institution in the service sector; one of the most important elements for the universities is to meet the expectations of the students. Satisfaction, which is expressed as the positive emotions perceived by individuals regarding the level of meeting the expectations from service received and the effectiveness of an environment or situation, is a phenomenon that should be examined in order to establish a quality standard in service and provide qualified service.

H3. Distance learning satisfaction perception levels of the participants significantly affect their career adoptability perception levels. 

Adoptability

Universities are not only places where individuals form their technical and professional knowledge infrastructure, but also, they are the institutions where individuals plan their future career choices. The sub-dimensions of the career adoptability cover the education process of the individual and influenced by the education received. In this context, this study examines the relationship between education satisfaction level and career adoptability level of the individuals who take education within open or distance education system. The reason for the selection of people from open or distance education system as the sample in the study is that the education model called as open or distance education model enables the individual to save time and space limitations, offers lifelong learning opportunities, provides employees to have education in a program that they desire and multiple career opportunities in their career process and provides an important opportunity to cope with the obstacles that may be encountered.

Methodology and research methods. The population of a study may be an institution, a professional group or demographic characteristics that are thought by the researcher to reflect the event or phenomenon examined in the best way (Miles \& Huberman, 1994). The population of this study is the participants who take education within the open and distance education system and work in different institutions in Ankara. The sample of the study consists of 517 participants determined through convenience sampling methods (Kothari, 2004).

In the study, a quantitative research method was preferred. The main purpose of the quantitative method is to generalize about the population and to increase the possibility of the results to represent the population (Morgan \& Morgan, 2008). Since the main purpose of the study is to form judgments about the target population, a «sampling frame» is needed to determine the appropriate sample and sample size from the target population and to represent the population successfully (Mertens, 2014). To be able to make accurate predictions and generalizations about the population of this study, which is designed with quantitative method, to affect the validity and consistency, to ensure that the sample size is appropriate to the homogeneous structure of the population and to prevent the selection of the wrong sampling method (Grix, 2010), it is required to determine the sampling frame. For this purpose, it has been tried to reach the participants who take open and distance education, have different demographic characteristics and work in public and private sectors through using a convenience sampling method.

Two data collection tools were used to find the answers to the research problems. The "CareerRelated Adaptability Scale» developed by Rottinghaus, Day, and Borgen (2005) was used to determine the career adaptability level of the participants and the «The Satisfaction Perceptions of the Distance Education Students» scale developed by Eygu and Karaman was used to determine perceptions of educational satisfaction of distance education students. The data collected in the study, which was designed according to the quantitative research method, was analysed with a difference, relationship and effect tests. In the study, it was examined whether there is a relationship between the participants' perceptions of educational satisfaction and career adaptation and whether the relationship is significantly different in terms of individual characteristics.

Results. In this study, to reach a general judgment about the population, a cross-sectional survey model, which is one of the general survey models, was preferred. In cross-sectional survey studies, measurements are made at a time in accordance with the characteristics of the variables to be described.

As a result of the reliability analysis performed to test the reliability of the study, the following Table 1 obtained. The point to look at in Table 1 is the Cronbach's alpha value. The following criteria should be considered while evaluating the alpha value (a):

- When $0,00 \leq a<0,4$, the scale is not reliable.

- When $0,4 \leq a<0,6$, the scale has low reliability.

- When $0,6 \leq a<0,8$, the scale is quite reliable.

- When $0,8 \leq a<1$, the scale is highly reliable. 
H. Tutar, O. Karademir, S. Guler \& S. Tutar. Management of Innovations in Education: Students Satisfaction and Career Adoptability

Table 1. Reliability Analysis

\begin{tabular}{|c|c|c|}
\hline & Career Adoptability & Education Satisfaction \\
\hline Cronbach Alpha & 0,749 & 0,940 \\
\hline N & 11 & 34 \\
\hline
\end{tabular}

Sources: developed by the author.

The reliability analysis showed that the career adoptability scale was highly reliable, and the educational satisfaction scale was reliable. Table 2 summarizes the demographic characteristics of the participants. According to the table, the gender and marital status distributions of the participants were close to each other. $88.43 \%$ (466 people) of the participants are undergraduate; $8.91 \%$ (47 people) are graduate and finally, $2.65 \%$ (14 people) are doctoral graduates. Most of the participants are graduated from Anadolu University, and their monthly income level is mostly between 2000-4000 and the age group is between 22-31 years.

Table 2. Demographic Variables

\begin{tabular}{|c|c|c|c|c|c|c|}
\hline Variables & \multicolumn{6}{|c|}{ Group } \\
\hline \multirow{2}{*}{ Gender } & Female & Male & & & & \\
\hline & 238 & 289 & & & & \\
\hline \multirow{2}{*}{ M.Status } & Married & Single & & & & \\
\hline & 260 & 267 & & & & \\
\hline \multirow{2}{*}{ Education } & Undergraduate & Graduate & $\mathrm{PhD}$ & & & \\
\hline & 466 & 47 & 14 & & & \\
\hline \multirow{2}{*}{ University } & Anadolu & Ataturk & Istanbul & & & \\
\hline & 390 & 117 & 20 & & & \\
\hline \multirow{2}{*}{ Income } & $0-1000$ & $1001-2000$ & $2001-3000$ & $3001-4000$ & 4001 and above & \\
\hline & 37 & 82 & 201 & 119 & 88 & \\
\hline \multirow{2}{*}{ Age } & $17-21$ & $22-26$ & $27-31$ & $32-36$ & $37-41$ & 42 and above \\
\hline & 32 & 180 & 146 & 90 & 42 & 37 \\
\hline
\end{tabular}

Sources: developed by the author.

In the analysis of the data, descriptive analysis techniques such as arithmetic mean, standard deviation; t-test to compare two variables, and one-way analysis of variance (ANOVA) to compare three or more variables were used. In the analysis of the data, SPSS 20 package program was used.

H1.a Differences in Career Adoptability and Education Satisfaction in terms of Gender Variable.

In Table 3, it was examined whether there was a significant difference between the participants' career adaptation and educational satisfaction according to their gender. As a result of analysis, it was found that there was a significant difference between gender and career adaptation with a significant value smaller than 0.05 . In other words, whether the participants are male or female leads to a meaningful difference between their perceptions of career adaptability. On the contrary, the differences in gender of the participants do not cause a difference in educational satisfaction. Accordingly, the $\mathrm{H} 1$ hypothesis stating that «Education satisfaction and career adoptability perception level of the students who take education within open and distance education system differs significantly in terms of demographic variables» is accepted for carrier adoptability and rejected for education satisfaction.

H1.b Differences in Career Adoptability and Education Satisfaction Level in Term of Marital Status Variable.

In Table 4, it was examined whether there was a significant difference between the participants' career adaptation and educational satisfaction according to their marital status variable. As a result of analysis, it was found that there was not a significant difference between career adaptability and education satisfaction levels in terms of the marital status variable with a significant value smaller than 0.05 . In other 

Adoptability

words, whether the participants are married or single does not lead to a meaningful difference between their perceptions of career adoptability and education satisfaction. Accordingly, the $\mathrm{H} 1$ hypothesis stating that «Education satisfaction and career adoptability perception level of the students who take education within open and distance education system differs significantly in terms of demographic variables» is rejected for both variables.

Table 3. Differences in Career Adoptability and Education Satisfaction in Terms of Gender Variable

\begin{tabular}{|c|c|c|}
\hline & \multicolumn{2}{|c|}{ Levene's Test for Equality of Variances } \\
\hline Variables & $\mathrm{F}$ & Sig. \\
\hline Career Adoptability & 9,702 & 0,002 \\
\hline Education Satisfaction & 1,132 & 0,288 \\
\hline
\end{tabular}

Sources: developed by the author.

Table 4. Differences in Career Adoptability and Education Satisfaction Level in Term of Marital Status Variable

\begin{tabular}{|c|c|c|}
\hline & \multicolumn{2}{|c|}{ Levene's Test for Equality of Variances } \\
\hline Variables & $\mathrm{F}$ & Sig. \\
\hline Career Adoptability &, 088 &, 767 \\
\hline Education Satisfaction & 3,237 &, 073 \\
\hline
\end{tabular}

Sources: developed by the author.

H1.c Differences in Career Adoptability and Education Satisfaction in Terms of Age Variable.

Table 5 shows whether there is a significant difference between participants' career adaptability and educational satisfaction according to the age variable. As a result of the analysis, it was found that there was a significant difference between career adaptability perceptions and education satisfaction level of the participants in terms of age variable with a significant value smaller than 0.05 .

Table 5. Differences in Career Adoptability and Education Satisfaction in Terms of Age Variable

\begin{tabular}{|c|c|c|c|c|c|c|}
\hline \multicolumn{7}{|c|}{ ANOVA } \\
\hline \multicolumn{2}{|c|}{ VARIABLES } & Sum of Squares & $\mathrm{df}$ & Mean Square & $\mathrm{F}$ & Sig. \\
\hline \multirow{3}{*}{ Career Adoptability } & Between Groups & 6,846 & 5 & 1,369 & 4,260 &, 001 \\
\hline & Within Groups & 167,478 & 521 & ,321 & & \\
\hline & Total & 174,324 & 526 & & & \\
\hline \multirow{3}{*}{ Education Satisfaction } & Between Groups & 7,958 & 5 & 1,592 & 4,468 & ,001 \\
\hline & Within Groups & 185,590 & 521 & ,356 & & \\
\hline & Total & 193,548 & 526 & & & \\
\hline
\end{tabular}

Sources: developed by the author.

Games-Howell analysis was performed in SPSS 20 package program in order to examine the significant difference between age groups in detail. The results showed that there was a significant difference between the students with 27-31 age range and above 37 for career adoptability perception since the sig. a value of less than 0.05 was obtained. On the other hand, the same analysis was conducted for education satisfaction and it was found that there was a significant difference between the participants with 42 and above age range and less than 31 . Accordingly, the $\mathrm{H} 1$ hypothesis stating that «Education satisfaction and career adoptability perception level of the students who take education within open and distance education system differs significantly in terms of demographic variables» is accepted for both variables. 
H. Tutar, O. Karademir, S. Guler \& S. Tutar. Management of Innovations in Education: Students Satisfaction and Career Adoptability

Table 6. Games-Howell Analizi (Age)

\begin{tabular}{|c|c|c|c|c|c|}
\hline Dependent Variable & Age Group (I) & Age Group (J) & Mean Difference (I-J) & Std. Error & Sig. \\
\hline \multirow{2}{*}{ Career Adoptability } & $27-31$ & $37-41$ &, $33614^{*}$ &, 11206 &, 045 \\
\cline { 2 - 6 } & & 42 ve uzeri &, $37446^{*}$ &, 11643 &, 027 \\
\hline \multirow{3}{*}{ Education Satisfaction } & 42 ve uzeri & $17-21$ &,$- 41646^{*}$ &, 13264 &, 029 \\
\cline { 2 - 6 } & & $22-26$ &,$- 39070^{*}$ &, 11032 &, 011 \\
\cline { 2 - 6 } & & $27-31$ &,$- 47086^{*}$ &, 11036 &, 001 \\
\hline
\end{tabular}

Sources: developed by the author.

H1.d Differences in Career Adoptability and Education Satisfaction in Terms of Education Variable.

Table 7 shows whether there is a significant difference between participants' career adaptability and educational satisfaction according to the education variable. As a result of the analysis, it was found that there was not a significant difference between career adaptability perceptions and education satisfaction level of the participants in terms of education variable with a significant value higher than 0.05 . Accordingly, the $\mathrm{H} 1$ hypothesis stating that «Education satisfaction and career adoptability perception level of the students who take education within open and distance education system differs significantly in terms of demographic variables» is rejected for both variables.

Table 7. Differences in Career Adoptability and Education Satisfaction in Terms of Education Variable

\begin{tabular}{|c|c|c|c|c|c|c|}
\hline \multicolumn{7}{|c|}{ ANOVA } \\
\hline \multicolumn{2}{|c|}{ VARIABLES } & Sum of Squares & df & Mean Square & $\mathrm{F}$ & Sig. \\
\hline \multirow{3}{*}{ Career Adoptability } & Between Groups & ,703 & 2 & ,352 & 1,061 & 347 \\
\hline & Within Groups & 173,621 & 524 & ,331 & & \\
\hline & Total & 174,324 & 526 & & & \\
\hline \multirow{3}{*}{ Education Satisfaction } & Between Groups & 1,286 & 2 & 643 & 1,752 & 174 \\
\hline & Within Groups & 192,262 & 524 & ,367 & & \\
\hline & Total & 193,548 & 526 & & & \\
\hline
\end{tabular}

Sources: developed by the author.

H1.e Differences in Career Adoptability and Education Satisfaction in Terms of Income Level Variable.

Table 8 shows whether there is a significant difference between participants' career adaptation and educational satisfaction according to income level variable. As a result of the analysis, it was found that there was a significant difference between the education satisfaction level of the participants in terms of income level variable with a sig. a value smaller than 0.05 while a significant difference is not obtained for career adoptability perceptions of the participants with a sig. a value higher than 0.05 . Accordingly, the $\mathrm{H} 1$ hypothesis stating that «Education satisfaction and career adoptability perception level of the students who take education within open and distance education system differs significantly in terms of demographic variables» is rejected for career adoptability and accepted for education satisfaction.

Games-Howell analysis was performed in order to find out where the significant difference among the groups was located. The results showed that significant and meaningful differences were obtained for education satisfaction level between the groups with 2001-3000 income level and 1001-2000- and 30014000-income level with a sig value smaller than 0.05 (Table 9).

$\mathrm{H} 1 \mathrm{f}$ Differences in Career Adoptability and Education Satisfaction in Terms of University Variable.

In Table 10, it was examined whether there was a significant difference between the participants' career adaptability and educational satisfaction according to university variable. As a result of the analysis, it was found that there was a significant difference between education satisfaction levels of the participants in terms of university variable with a sig. a value smaller than 0.05 while there was not a significant 
H. Tutar, O. Karademir, S. Guler \& S. Tutar. Management of Innovations in Education: Students Satisfaction and Career Adoptability

difference between career adaptation perceptions of the participants in terms of university variable with a sig. a value higher than 0.05 . Accordingly, the $\mathrm{H} 1$ hypothesis stating that «Education satisfaction and career adoptability perception level of the students who take education within open and distance education system differs significantly in terms of demographic variables» is accepted for education satisfaction level and rejected for career adaptability perception.

Table 8. Differences in Career Adoptability and Education Satisfaction in Terms of Income Level Variable

\begin{tabular}{|c|c|c|c|c|c|c|}
\hline \multicolumn{7}{|c|}{ ANOVA } \\
\hline \multicolumn{2}{|c|}{ VARIABLES } & Sum of Squares & df & Mean Square & $\mathrm{F}$ & Sig. \\
\hline \multirow{3}{*}{ Career Adoptability } & Between Groups & 1,582 & 4 & ,896 & 2,038 & 078 \\
\hline & Within Groups & 170,742 & 522 & 327 & & \\
\hline & Total & 174,324 & 526 & & & \\
\hline \multirow{3}{*}{ Education Satisfaction } & Between Groups & 6,118 & 4 & 1,530 & 4,260 &, 002 \\
\hline & Within Groups & 187,430 & 522 & ,359 & & \\
\hline & Total & 193,548 & 526 & & & \\
\hline
\end{tabular}

Sources: developed by the author.

Table 9. Games-Howell Analysis (Income Level)

\begin{tabular}{|c|c|c|c|c|c|}
\hline Dependent Variable & Income Level (I) & Income Level (J) & Mean Difference (I-J) & Std. Error & Sig. \\
\hline \multirow{2}{*}{ Education Satisfaction } & $2001-3000$ & $1001-2000$ &, $21659^{*}$ &, 06853 &, 016 \\
\cline { 2 - 6 } & & $3001-4000$ &, $24911^{*}$ &, 07047 &, 004 \\
\hline
\end{tabular}

Sources: developed by the author.

Table 10. Differences in Career Adoptability and Education Satisfaction in Terms of University Variable

\begin{tabular}{|c|c|c|c|c|c|c|}
\hline \multicolumn{9}{|c|}{ ANOVA } \\
\hline \multirow{4}{*}{ VARIABLES } & Sum of Squares & df & Mean Square & F & Sig. \\
\hline \multirow{3}{*}{ Career Adoptability } & Between Groups & 1,891 & 2 &, 946 & 2,874 &, 057 \\
\cline { 2 - 7 } & Within Groups & 172,433 & 524 &, 329 & & \\
\cline { 2 - 7 } & Total & 174,324 & 526 & & & \\
\hline \multirow{3}{*}{ Education Satisfaction } & Between Groups & 5,181 & 2 & 2,591 & 7,207 &, 001 \\
\cline { 2 - 7 } & Within Groups & 188,367 & 524 &, 359 & & \\
\cline { 2 - 7 } & Total & 193,548 & 526 & & & \\
\hline
\end{tabular}

Sources: developed by the author.

Games-Howell analysis was performed in order to find out where the significant difference among the groups was located. The results showed that significant and meaningful differences were obtained for education satisfaction level between the participants who graduated from Anadolu University and Ataturk University (Table 11). On the other hand, significant differences were not obtained between the participants graduated from Istanbul University and the other two universities.

Table 11. Games-Howell Analysis (University)

\begin{tabular}{|c|c|c|c|c|c|}
\hline Dependent Variable & University (I) & University (J) & Mean Difference (I-J) & Std. Error & Sig. \\
\hline \multirow{2}{*}{ Education Satisfaction } & Anadolu University & Ataturk University &,$- 20831^{*}$ &, 05567 &, 001 \\
\cline { 2 - 6 } & Istanbul University & Anadolu University &,- 20945 &, 17690 &, 476 \\
\hline & & Ataturk University &,- 41776 &, 18012 &, 074 \\
\hline
\end{tabular}

Sources: developed by the author. 

Adoptability

Correlation analysis is performed to determine the direction and strength of the linear relationship between two random variables. Although different correlation coefficients have been developed for different situations, the Pearson correlation coefficient is the most widely known and widely used in the social sciences. Pearson correlation coefficient is obtained by dividing the covariance of the two random variables by the product of the standard deviations of these two random variables.

This coefficient has a value between $(-1)$ and $(+1)$. A positive coefficient represents a directional linear relationship between variables, and a negative coefficient represents a linear directional relationship between variables (Altindag, 2011: 106). As the absolute value of the coefficient approaches 1, the strength of the relationship between the two variables increases. Islamoglu and Alniacik (2014: 347) stated:

- the values between 0.1 and 0.3 show weak correlation;

- the values between 0.3 and 0.5 show medium level correlation;

- the values between 0.5 and 0.8 show strong correlation;

- the values greater than 0.8 shows a very strong correlation.

The fact that this coefficient is $(0)$ indicates that there is no linear relationship between variables included in the research. Pearson correlation analysis was used in this study to determine whether there is a significant relationship between career adoptability and education satisfaction variables. When the correlation between career adaptability perception and education satisfaction level was examined, a significant, moderate level and positive correlation of 0.485 was obtained with a sig. a value smaller than 0.05 (Table 12). Career-Related Adoptability scale consists of two factors as complementary and integrative. Education satisfaction perception scale consists of eight factors namely individual suitability, effectiveness, learning, evaluation, technology, materials, system and support. When the relationships between the factors of Career-Related Adoptability Scale and education satisfaction scales are examined, the following table is obtained. According to the table, there is a significant relationship between all factors. Accordingly, the $\mathrm{H} 2$ hypothesis stating that «There is a significant relationship between the participants' perception of distance education satisfaction and their career adoptability» was accepted.

Table 12. Relationship between Career Adoptability and Education Satisfaction

\begin{tabular}{|c|c|c|c|}
\hline \multicolumn{4}{|c|}{ Correlations } \\
\hline \multirow{3}{*}{ Career Adoptability } & Cearson Correlation & 1 & Education Satisfaction \\
\cline { 2 - 4 } & Sig. (2-tailed) & &, $485^{* *}$ \\
\cline { 2 - 4 } & $\mathrm{N}$ & 527 &, 000 \\
\hline \multirow{3}{*}{ Education Satisfaction } & Pearson Correlation &, $485^{* *}$ & 527 \\
\cline { 2 - 4 } & Sig. (2-tailed) &, 000 & 1 \\
\cline { 2 - 4 } & $\mathrm{N}$ & 527 & 527 \\
\hline & $* *$ Correlation is significant at the 0.01 level (2-tailed). \\
\hline
\end{tabular}

Sources: developed by the author.

Regression analysis is a statistical analysis which is used to convert the relationships between variables into numerical values. Regression analysis aims to determine the severity of the relationship/effect between variables in a mathematical relationship.

Correlation analysis shows whether there is a relationship between two or more variables and if there is a relationship, the direction and magnitude of this relationship. On the other hand, regression analysis is the method used to determine the extent to which a unit change in any of the variables will affect other variables (Table 13). 
H. Tutar, O. Karademir, S. Guler \& S. Tutar. Management of Innovations in Education: Students Satisfaction and Career Adoptability

Table 13. Correlation analysis results between the factors

\begin{tabular}{|c|c|c|c|c|c|c|c|c|c|c|c|}
\hline & & 1 & 2 & 3 & 4 & 5 & 6 & 7 & 8 & 9 & 10 \\
\hline \multirow{2}{*}{1} & Corr. & 1 & & & & & & & & & \\
\hline & Sig & & & & & & & & & & \\
\hline \multirow{2}{*}{2} & Corr. &, $128^{* \star}$ & 1 & & & & & & & & \\
\hline & Sig & ,003 & & & & & & & & & \\
\hline \multirow{2}{*}{3} & Corr. & ,241** & $333^{* *}$ & 1 & & & & & & & \\
\hline & Sig & , 000 & ,000 & & & & & & & & \\
\hline \multirow{2}{*}{4} & Corr. &, $247^{* *}$ & $292^{* \star}$ &, $511^{* *}$ & 1 & & & & & & \\
\hline & Sig & ,000 & ,000 & ,000 & & & & & & & \\
\hline \multirow{2}{*}{5} & Corr. & $360^{* *}$ &, $245^{* *}$ &, $508^{\star \star}$ &, $472^{* \star}$ & 1 & & & & & \\
\hline & Sig & ,000 & ,000 &, 000 & 000 & & & & & & \\
\hline \multirow{2}{*}{6} & Corr. &, $277^{* *}$ & $142^{\star *}$ &, $331^{* *}$ &, $385^{\star *}$ &, $485^{\star *}$ & 1 & & & & \\
\hline & Sig & , 000 & ,001 & , 000 & ,000 & , 000 & & & & & \\
\hline \multirow{2}{*}{7} & Corr. & $132^{* *}$ & $297^{* *}$ & $422^{* \star}$ &, $547^{* *}$ & $416^{* *}$ & $391^{* *}$ & 1 & & & \\
\hline & Sig & ,002 & ,000 & ,000 & 000 & , 000 & ,000 & & & & \\
\hline \multirow{2}{*}{8} & Corr. &, $372^{* \star}$ & $180^{* *}$ &, $382^{* \star}$ &, $441^{* *}$ &, $521^{* *}$ & $460^{* *}$ & $378^{* *}$ & 1 & & \\
\hline & Sig & , 000 & ,000 & , 000 & ,000 & , 000 & ,000 & , 000 & & & \\
\hline \multirow{2}{*}{9} & Corr. &, $375^{* \star}$ & $190^{* *}$ & $331^{* \star}$ & ,439** & $434^{* *}$ & $392^{* *}$ & $308^{* *}$ & ,645** & 1 & \\
\hline & Sig & , 000 & ,000 & ,000 & , 000 & ,000 & , 000 & , 000 & ,000 & & \\
\hline \multirow{2}{*}{10} & Corr. &, $346^{* *}$ & $200^{* *}$ &, $393^{* *}$ &, $447^{* \star}$ & $444^{\star *}$ &, $408^{* *}$ &, $291^{* *}$ &, $574^{\star *}$ &, $652^{* *}$ & 1 \\
\hline & Sig & ,000 & , 000 & , 000 & 000 & , 000 & 000 & 000 & 000 & 000 & \\
\hline
\end{tabular}

Sources: developed by the author.

Model1: EDUCATION $=a+b_{1}$ support $+b_{2}$ technology $+b_{3}$ learning $+b_{4}$ effectiveness $+b_{5}$ material + $b_{6}$ evaluation $+b_{7}$ individual suitability $+b_{8}$ system.

In the multiple regression model, the explanatory power of the model is determined by the adjusted $\mathrm{R}$ square value (Table 14).

\begin{tabular}{|c|c|c|c|c|}
\hline Model & $\mathbf{R}$ & $\mathbf{R}$ Square & Adjusted R Square & Std. The error of the Estimate \\
\hline 1 &, $992^{\mathrm{a}}$ &, 983 &, 983 &, 07823 \\
\hline \multicolumn{4}{|c|}{ a. Predictors: (Constant), Usupport, Utechnology, Ulearning, Ueffectiveness, Umaterial, Uevaluation, } \\
Uindividual suitability, Usystem \\
\hline
\end{tabular}

Sources: developed by the author.

The explanatory power of the model, which was established to determine the level of impact among education satisfaction factors in the scale, was obtained as $98.3 \%$. Moreover, since the sig. value of the model in the ANOVA table is less than 0.05 , the model is significant (Table 15).

Table 15. Anova

\begin{tabular}{|c|c|c|c|c|c|c|}
\hline \multicolumn{2}{|c|}{ Model } & Sum of Squares & Df & Mean Square & F & Sig. \\
\hline \multirow{3}{*}{1} & Regression & 188,676 & 8 & 23,585 & 3853,706 &, $000^{\mathrm{b}}$ \\
\cline { 2 - 7 } & Residual & 3,170 & 518 &, 006 & & \\
\cline { 2 - 6 } & Total & 191,847 & 526 & & & \\
\hline \multicolumn{6}{|c|}{ a. Dependent Variable: EDUCATION } \\
\hline \multicolumn{6}{|c|}{ b. Predictors: (Constant), Usupport, Utechnology, Ulearning, Ueffectiveness, Umaterial, Uevaluation, } \\
\end{tabular}

Sources: developed by the author. 
H. Tutar, O. Karademir, S. Guler \& S. Tutar. Management of Innovations in Education: Students Satisfaction and Career Adoptability

The coefficients table shows the effect of a one-unit change in the factors created in the model on the level of education satisfaction. The effect of each factor on the level of education satisfaction is significant (sig <0.05) and one-unit change in each factor affects the level of education satisfaction in the same direction (0.117 units to 0.133 units) (Table 16).

Table 16. Model 1 Coefficients Table

\begin{tabular}{|c|c|c|c|c|c|c|}
\hline \multicolumn{7}{|c|}{ Coefficients } \\
\hline & \multirow{2}{*}{ Model } & \multicolumn{2}{|c|}{ Unstandardized Coefficients } & \multirow{3}{*}{$\begin{array}{c}\text { Standardized Coefficients } \\
\text { Beta } \\
\end{array}$} & \multirow{2}{*}{$\mathrm{t}$} & \multirow{2}{*}{ Sig. } \\
\hline & & $B$ & Std. Error & & & \\
\hline \multirow{9}{*}{1} & (Constant) & ,003 & ,021 & & 145 & ,884 \\
\hline & Uindividual suitability & ,126 & ,007 & 154 & 18,603 &, 000 \\
\hline & Ueffectiveness & ,124 &, 006 & 163 & 20,562 &, 000 \\
\hline & Ulearning & 133 &, 006 & 170 & 21,643 &, 000 \\
\hline & Uevaluation & ,117 &, 006 & , 143 & 18,006 &, 000 \\
\hline & Utechnology & 130 &, 004 &, 215 & 30,065 &, 000 \\
\hline & Umaterial & ,121 &, 006 & , 158 & 18,954 &, 000 \\
\hline & Usystem & ,124 &, 006 & ,161 & 19,259 &, 000 \\
\hline & Usupport & 126 &, 006 & ,177 & 21,936 &, 000 \\
\hline
\end{tabular}

Sources: developed by the author.

Model2: CAREER: $a+b_{1}$ integrative $+b_{2}$ complementary

In the multiple regression model, the explanatory power of the model is determined by the adjusted $R$ square value. The explanatory power of the model, which was established to determine the level of impact among career adoptability perception and the factors in Career-Related Adoptability Perception scale, was obtained as $99.7 \%$ (Table 17). Moreover, since the sig value of the model in the ANOVA table is less than 0.05 , the model is significant (Table 18).

Table 17. Model Summary

\begin{tabular}{|c|c|c|c|c|}
\hline Model & R & R Square & Adjusted R Square & Std. The error of the Estimate \\
\hline 1 &, $998^{\mathrm{a}}$ &, 997 &, 997 &, 03154 \\
\hline \multicolumn{5}{|c|}{ a. Predictors: (Constant), KIntergrative, KComplementary } \\
\hline
\end{tabular}

Sources: developed by the author.

Table 18. ANOVA

\begin{tabular}{|c|c|c|c|c|c|c|}
\hline \multicolumn{2}{|c|}{ Model } & Sum of Squares & df & Mean Square & F & Sig. \\
\hline \multirow{3}{*}{1} & Regression & 160,382 & 2 & 80,191 & 80598,026 &, $000^{\mathrm{b}}$ \\
\cline { 2 - 7 } & Residual &, 521 & 524 &, 001 & & \\
\cline { 2 - 6 } & Total & 160,903 & 526 & & \\
\hline \multicolumn{6}{|c|}{ a. Dependent Variable: CAREER } \\
\hline \multicolumn{7}{|c|}{ b. Predictors: (Constant), KIntergrative, KComplementary } \\
\end{tabular}

Sources: developed by the author.

In the coefficients table, the effect of a one-unit change in the factors created in the model on the level of career adoptability perception is presented. The effect of each factor on the level of career adoptability perception is significant (sig <0.05). One unit increase in complementary independent variable increases career adoptability by 0.499 units. The one-unit increase in the integrative independent variable increases career adoptability by 0.505 units (Table 19). 
H. Tutar, O. Karademir, S. Guler \& S. Tutar. Management of Innovations in Education: Students Satisfaction and Career Adoptability

Table 19. Model 2 Coefficients Table

\begin{tabular}{|c|c|c|c|c|c|c|}
\hline \multicolumn{7}{|c|}{ Coefficients } \\
\hline \multirow{2}{*}{\multicolumn{2}{|c|}{ Model }} & \multicolumn{2}{|c|}{ Unstandardized Coefficients } & \multirow{2}{*}{$\begin{array}{c}\text { Standardized Coefficients } \\
\text { Beta }\end{array}$} & \multirow{2}{*}{$\mathrm{t}$} & \multirow{2}{*}{ Sig. } \\
\hline & & B & Std. Error & & & \\
\hline \multirow{3}{*}{1} & (Constant) &,- 011 & ,009 & & $-1,194$ & ,233 \\
\hline & KComplementary & ,499 & ,002 & ,639 & 254,388 & ,000 \\
\hline & KIntegrative & ,505 & ,002 & ,681 & 271,181 & ,000 \\
\hline \multicolumn{7}{|c|}{ a. Dependent Variable: CAREER } \\
\hline
\end{tabular}

Sources: developed by the author.

Model3: CAREER $=a+b_{1}$ EDUCATION

In the multiple regression model, the explanatory power of the model is determined adjusted $\mathrm{R}$ square value (Table 20). The explanatory power of the model which was established to determine the interaction between career adoptability perception and education satisfaction was obtained as $25 \%$. Moreover, since the sig value of the model in the ANOVA table is less than 0.05 , the model is significant (Table 21).

Table 20. Model Summary

\begin{tabular}{|c|c|c|c|c|}
\hline Model & $\mathbf{R}$ & R Square & Adjusted R Square & Std. The error of the Estimate \\
\hline 1 &, $500^{\mathrm{a}}$ &, 250 &, 249 &, 52335 \\
\hline \multicolumn{5}{|c|}{ a. Predictors: (Constant), EDUCATION } \\
\hline
\end{tabular}

Sources: developed by the author.

Table 21. Anovaa

\begin{tabular}{|c|c|c|c|c|c|c|}
\hline \multicolumn{2}{|c|}{ Model } & Sum of Squares & $\mathbf{d f}$ & Mean Square & $\mathbf{F}$ & Sig. \\
\hline \multirow{3}{*}{1} & Regression & 48,049 & 1 & 48,049 & 175,427 &, $000 \mathrm{~b}$ \\
\cline { 2 - 7 } & Residual & 143,797 & 525 &, 274 & & \\
\cline { 2 - 7 } & Total & 191,847 & 526 & & \\
\hline \multicolumn{7}{|c|}{ a. Dependent Variable: Career Adoptability } \\
\hline \multicolumn{7}{|c|}{ b. Predictors: (Constant), Education Satisfaction } \\
\hline
\end{tabular}

Sources: developed by the author.

In the model created in the coefficients table, the effect of a one-unit change in the perception of career adaptability on education satisfaction is shown. The effect of career adaptability perception on educational satisfaction level was significant ( $\mathrm{sig}<0.05$ ). The model is constructed as follows with the values obtained from the coefficients table:

Model3: CAREER $=1,609+0,546$ EDUCATION

One-unit change in educational satisfaction positively affects career adoptability level and increases by 0.546 units (Table 22 ).

Table 22. Model 3 Coefficients Table

\begin{tabular}{|c|c|c|c|c|c|c|}
\hline \multicolumn{7}{|c|}{ Coefficients } \\
\hline \multirow{2}{*}{ Model } & \multicolumn{2}{|c|}{ Unstandardized Coefficients } & Standardized Coefficients & \multirow{2}{*}{ Sig. } \\
\cline { 3 - 6 } & B & Std. Error & Beta & & \\
\hline \multirow{2}{*}{1} & (Constant) & 1,609 &, 149 & & 10,777 &, 000 \\
\cline { 2 - 7 } & Education Satisfaction &, 546 &, 041 &, 500 & 13,245 &, 000 \\
\hline \multicolumn{7}{|c|}{ a. Dependent Variable: Career Adoptability } \\
\hline
\end{tabular}

Sources: developed by the author. 

Adoptability

Accordingly, the H3 hypothesis stating that «Distance learning satisfaction perception levels of the participants significantly affect their career adoptability perception levels» was accepted.

Conclusions. Career adaptability, which means the ability to adapt and cope with changes in business life, has become a more important concept in the period of rapid change, which is one of the effects of the era of digitalization. Career adoptability levels of individuals depend on personality traits such as interest, curiosity, desire to control and perception of trust. In studies related to career adoptability in the literature; Klehe et al., (2012) examined the relationship between career adoptability and job finding potential and found a positive relationship between these variables. Siyez and Yusupu (2015) examined career adoptability in terms of gender variable and found that the career adoptability levels of male individuals were higher than female individuals. Educational satisfaction, which is the other variable of the research, is related to the level of satisfaction of graduates towards the institution they graduated from, and this is a multi-dimensional phenomenon. This phenomenon includes different dimensions such as the quality of education provided in the institution, physical spaces, opportunities offered and personality characteristics of individuals. As a result of the analysis conducted taking into consideration the age of the participants, it was found that there was a statistically significant difference between age and career adoptability perception and education satisfaction level. Accordingly, the educational satisfaction level of the participants between 42 and over varies significantly concerning younger age groups. As a reason for the difference between educational satisfaction levels of the participants in the open education system, it is interpreted that the new generation or the age group that can be accepted as middle age has access to technological innovations and different educational technologies and systems, which leads to a decrease in the satisfaction levels of the education they are in. As a result of the analysis conducted according to the gender of the participants, there was a statistically significant difference in career adoptability, but no significant difference was found in terms of educational satisfaction. On the other hand, no statistically significant difference was found between the level of education satisfaction and career adoptability in terms of education variable. Career adoptability changes according to internal factors such as personality characteristics rather than external factors such as education level. Similarly, the education satisfaction level is generally affected by internal factors. Therefore, these factors can be the reasons for not obtaining significant differences in terms of the education variable.

As a result of the analysis conducted according to income levels of the participants, it was found that there was a statistically significant difference between educational satisfaction according to income level. It was found that this difference was in favour of the participants with an income level between 2001-3000 $\mathrm{TL}$. The reason for this situation may be the fact that these participants take part in the middle-income group in Turkey and they are in a pessimistic attitude towards the events. As a result of the analysis conducted in order to test whether the participants' career adoptability and educational satisfaction differ according to the university they graduated from, it was found that the level of career adoptability did not differ significantly according to the university graduated from, but significant differences were obtained in terms of education satisfaction level. One of the important results of the research is that the perception of education satisfaction of the participants in the education at Istanbul University is higher than the Anadolu University and Ataturk University. Correlation analysis, which was conducted to determine the relationship between career adoptability and education satisfaction, showed that there was a statistically significant and positive $(0.485)$ relationship between career adoptability and education satisfaction. It can be put forward as an assumption that people who are satisfied with the institution, they are educated can cope with the problems in their career life more easily. The regression model where education satisfaction was determined as dependent and career adoptability as the independent variable was statistically significant $(F=175.427 ; p=0.000)$; the effective coefficient of the model was 0.546 and the total variance was $25 \%$. Beta coefficient is $+0,546$ and it shows that educational satisfaction has a positive effect on career adoptability. In conclusion, the findings of this study should be repeated with qualitative data collection 
techniques and data obtained from the participants should be supported with content analysis. Thus, it can be argued that the results obtained with different samples and methods can be generalized to the research population.

As a result, it should be stated that it is beneficial to use different samples and to add different independent variables to the research concerning the educational satisfaction of the participants and career adoptability. Besides, a five-factor personality trait scale can be included in the study, and therefore a more comprehensive study could be conducted with a model to see whether the personality traits have a moderator effect. In this study, repeating the findings obtained with quantitative methods with qualitative methods and comparing the results will contribute to the literature.

Author Contributions. Conceptualization, H. T. and S. G.; data curation, S. T.; formal analysis, S. T.; investigation, O.K.; supervision, H. T.; validation, H. T. and S. T.; Visualization, O. K.; Writing - original draft, H. T., S. T. and S. G.; Writing - review \& editing, H. T., S. G., O. K., S. T.

\section{References}

Altindag, E. (2011), Aile Sirketlerinde Stratejik Yonelim Duzeylerinin Tespiti ve Firma Performansi Uzerindeki Etkisi, Gebze Yuksek Teknoloji Enstitusu Sosyal Bilimler Enstitusu, Istanbul.

Aydin C. H. (2011). Acik veya Uzaktan Ogrenme: Ogrenci Adaylarinin Bakis Acisi. Ankara: Pegem Yayinlari.

Eygu H., Kahraman S. (2013). Uzaktan Egitim Ogrencilerinin Memnuniyet Algilari Uzerine Bir Arastirma, Kirikkale Universitesi Sosyal Bilimler Dergisi, 3(1), 36-59.

Grix, J. (2010). The Foundations of Research. London: Palgrave Macmillan. G Journal of Social And Humanities Sciences Research (JSHSR) 2018, 5(22), 1039-1052.

Islamoglu, H., Alniacik, U., (2014), Sosyal Bilimlerde Arastirma Yontemleri, (4. Baski), Beta Yayincilik, Istanbul.

Kalafat, T. (2012). Kariyer Gelecegi Olcegi (KARGEL): Turk Orneklemi icin Psikometrik Ozelliklerinin Incelenmesi. Turk Psikolojik Danisma ve Rehberlik Dergisi, 4(38), 169-179.

Klehe, U.-C., Zikic, J., Van Vianen, A. E. M., Koen, J., Buyken, M. B. W. (2012). Coping proactively with economic stress: Career adaptability in the face of job insecurity, job loss, unemployment, and underemployment. In P. L. Perrewe, J. R.B. Halbesleben, C C. Rosen (Eds.). Research in Occupational Stress and Well-being. Volume 10 - The Role of the Economic Crisis on Occupational Stress and Well Being (131-176).

Knapper, C. K., Cropley, A. J. (2000) Lifelong Learning in Higher Education, 3rd edn (London: Kogan Page).

Kosar, E. Digerleri (2003). Ogretim Teknolojileri ve Materyal Gelistirme, 2.Baski, Ankara: Ogreti, PagemA Yayinlari.

Kothari, C. R. (2004). Research Methodology: Methods and Techniques. New Age International.

Longworth, N., Davies, W. K., Lifelong Learning: New Visions, New Implications, New Roles - for Industry, Government,

Education and the Community for the 21st Century. London: Kogan Page, 1996.

McMillan, J. H. (1996). Educational Research: Fundamentals for the Consumer. New York: HarperCollins College Publishers.

Mertens, D. M. (2014). Research and Evaluation in Education and Psychology: Integrating Diversity with Quantitative,

Qualitative, and Mixed Methods. New York.

Michael W. Galbraith, Melanie S. Jones (2012), Theory to Practice Creativity: Essential for the Adult Education Instructor and Learner, PAACE Journal of Lifelong Learning, 21 (2012), 51-59.

Miles, M. B., Huberman, A. M. (1994). Qualitative Data Analysis: An Expanded Sourcebook. New York: Sage.

Moore, M., G., Kearsley G., (2011), Distance Education: A Systems View of Online Learning. Cengage Learning, CA.

Morgan, D. L., Morgan, R. K. (2008). Single-Case Research Methods for the Behavioral and Health Sciences. SAGE

Publications. Journal of Social And Humanities Sciences Research (JSHSR), 5(22), 1039-1052.

Ozer, B., (1990). Uzaktan Egitim Sisteminin Evrensel Yapisi. Kurgu: Anadolu Universitesi Acikogretim Fakultesi lletisim Bilimleri Dergisi, 8, 569-594

Rottinghaus, P. J., Day, S. X., Borgen, F. H. (2005). The career futures inventory: A measure of career-related adaptability and optimism. Journal of Career Assessment, 13(1), 3-24.

Savickas, M. L. (1997). Career adaptability: An integrative construct for life span, life-space theory. The Career Development Quarterly, 45, 247-259.

Savickas, M. L. (2011). Career counseling. Washington, DC: American Psychological Association Books.

Savickas, M. L., Porfeli, E. J. (2012). Career adapt-abilities scale: Construction, reliability, and measurement equivalence across 13 countries. Journal of Vocational Behavior, 80(3), 661-673.

Schlosser, L., A., M., R., Simonson (2009), Distance Education: Definitions and Glossary of Terms, Information Age Publishing (IAP) Inc., North Carolina. 
H. Tutar, O. Karademir, S. Guler \& S. Tutar. Management of Innovations in Education: Students Satisfaction and Career Adoptability

Siyez, D. M., Yusupu, R. (2015). Universite ogrencilerinde kariyer uyumlulugu ve kariyer iyimserliginin cinsiyet rolu degiskenine gore incelenmesi. Is, Guc Endustri lliskileri ve Insan Kaynaklari Dergisi, 17(1), 78-88.

Super, D. E., Knasel, E. G. (1981). Career development in adulthood: Some theoretical problems and a possible solution. British Journal of Guidance \& Counseling, 9, 194-201.

Verduin, J. R. Clark, T. A (1994). Uzaktan Egitim: Etkin Uygulama Esaslari (Cev.: Ilknur Mavis), 1. Baski, Eskisehir: Anadolu Universitesi Basimevi.

Хасан Tymap, Dr.Sc., профресор, Анадолуський університет (Туреччина);

Омер Карадемір, Університет Сакарія (Туреччина);

Севілай Гулер, Університет Сакарія (Туреччина);

Салих Тутар, Університет прикладних наук Сакарія (Туреччина).

Управління інноваціями в освіті: рівень задоволеності студентів та їх працевлаштування

Особливість онлайн та дистанційної форми навчання, на відміну від традиційної форми, полягає у відсутності необхідності безпосередньої присутності у навчальній аудиторії, так як навчання відбувається у віртуальному середовищі з використанням інформаційних технологій. При цьому, як правило, застосовуються інтерактивні методи навчання, що у свою чергу дають можливість студентам користуватись навчальним матеріалом в будь-який час. У статті визначено, що онлайн та дистанційна форма навчання $\epsilon$ ідеальною освітньою моделлю для тих, хто не може скористатися традиційною моделлю, надаючи рівні можливості для осіб з обмеженими можливостями, а також усуваючи географрічні та регіональні бар'єри. Крім того, це сучасна та інноваційна модель освіти, яка забезпечує продовження навчання у продовж життя. Авторами зазначено, що сучасні тренди світового розвитку провокують зміну парадигми і вимог до навичок та знань як випускників, так і працівників. Нові тенденції обумовлюють необхідність постійного навчання на всіх етапах: підготовка до працевлаштування, кар'єрне зростання та завершення кар'єри. У иьому аспекті, невід'ємною вимогою успішного кар'єрного зростання є здатність працівників швидко адаптуватись до нових вимог. Основною метою статті $\epsilon$ аналіз взаємозв'язків між рівнями задоволеності освітою та відповідності до кар'єрних вимог осіб, які отримують освіту в рамках онлайн або дистанційної моделі навчання. Авторами зазначено, що актуальність дослідження обумовлена необхідністю вдосконаленням онлайн та дистанційної форми навчання. Визначено, що кількість осіб, які отримують освіту в рамках даної форми навчання в Туреччині становить більше трьох з половиною мільйонів. У статті висунуто гіпотезу про позитивний вплив рівня задоволеності дистанційною освітою на відповідність кар'єрним вимогам. Дані для аналізу згенеровано на основі результатів опитування 527 респондентів. У статті використано тести на перевірку різниць, взаємозв'язків та взаємовпливів між визначеними змінними. Емпіричні результати підтвердили гіпотезу, що рівень задоволеності навчанням має статистично значущий позитивний вплив на рівень відповідності кар'єрним вимогам.

Ключові слова: освіта, адаптованість, кар'єра, дистанційне навчання, електронне навчання.

Manuscript received: 15.05.2019.

(C) The author(s) 2019. This article is published with open access at Sumy State University. 